THE STATE OF IS IN AUSTRALIAN UNIVERSITIES - NEW SOUTH WALES REPORT

\title{
Jim Underwood
}

\author{
Department of Information Systems, \\ University of Technology, Sydney \\ jim@it.uts.edu.au
}

\section{Ernie Jordan}

\author{
Graduate School of Management \\ Macquarie University, Sydney \\ ernest.jordan@mgsm.edu.au
}

\begin{abstract}
This paper, examining Information Systems in New South Wales universities, highlights the significance of New South Wales as the most populous state in Australia. Rather than offering a comprehensive coverage of all Information Systems courses in the state, the paper gives a broad overview of Information Systems in the state's universities while seeking to highlight the distinctive characteristics of some of the universities, deemed to have particular significance in the state. The view portrayed is of an environment threatening the continuing existence of Information Systems in some of the state's universities. Again, the state of Information Systems research in the state's universities is characterised by diversity and limited collaboration.
\end{abstract}

\section{INTRODUCTION}

The Information and Communications Technology (ICT) industry is a significant part of the NSW economy, ranking $17^{\text {th }}$ in the world according to a NSW government report (NSW, 2001). This report also suggests that this significance is reflected in some $70 \%$ of the top 250 Australian IT head offices being located in NSW. There are long established university programs that support this economy. As the most populous state, it is natural that there are more universities and more programs to report on. This report will concentrate on those universities that have been most significant in the development of the IS discipline in NSW and give outline information for the others. The basis for this selection will be explained in the following section of the report. The universities that are reported in detail are University of New South Wales (UNSW), the University of Sydney, Wollongong University, University of Technology Sydney (UTS) and Charles Sturt University. 


\section{Overview of the IS Presence in NSW Universities}

As some universities have more than one administrative entity that is concerned with IS, these are shown separately in Table 1 below.

The University of NSW has had an historical place in the development of IS in Australia going back to the leadership of Cyril Brookes. This place has wavered over time but the school remains a significant player in IS research and education. UTS also has a long history of IS that has complemented and competed with UNSW. Both of these have organisational units with names including IS and the only other such unit is the formal 'discipline' of IS at Wollongong. This alone merits their in-depth treatment. The only other university that is considered in detail is U Sydney, for two reasons. First, the relatively recent establishment of a ‘discipline group' of IS in the Faculty of Commerce is seen to be a strategic move warranting consideration, and second, the significant status and historic role of the Dept of Computer Science and its IS members. Charles Sturt University has long had IS related courses, and has been a major provider of distance learning. Here we discuss mainly the Riverina operation, which has been closely associated with library studies.

Dealing with the other units in turn, University of Western Sydney (UWS) had a long term role going back to data processing days, but this is much reduced today. Macquarie University has several IS degrees, including majors in the Bachelor of Business Administration (BBA) but the few IS faculty remain fragmented. Southern Cross University (SCU) has significant distance education enrolments and is a relatively new entrant in the marketplace with some significant innovation. Their influence on the discipline in NSW is as yet not large, but the research activity at SCU in particular could establish a future place. Both University of New England (UNE) and Newcastle are under-developed in terms of IS. We now present an outline of the five identified universities.

\begin{tabular}{|c|c|c|c|}
\hline University & Administrative entity & Home faculty & No. of IS \\
\hline UNSW & $\begin{array}{l}\text { School of Information } \\
\text { Systems, Technology and } \\
\text { Management }\end{array}$ & $\begin{array}{l}\text { Commerce and } \\
\text { Economics }\end{array}$ & 20 \\
\hline UNSW & Group & AGSM & 1 \\
\hline U Sydney & Group in School of IT & Science & ca.5 \\
\hline U Sydney & $\begin{array}{l}\text { Business IS 'Discipline' in } \\
\text { School of Business }\end{array}$ & $\begin{array}{lr}\text { Faculty } & \text { of } \\
\text { Business } & \text { and } \\
\text { Economics } & \\
\end{array}$ & 12 \\
\hline UTS & Dept of Information Systems & $\begin{array}{l}\text { Information } \\
\text { Technology }\end{array}$ & 20 \\
\hline U Wollongong & $\begin{array}{l}\text { 'Discipline' of IS in School of } \\
\text { Economics and Information } \\
\text { Systems }\end{array}$ & Commerce & 15 \\
\hline U Western Sydney & $\begin{array}{l}\text { Group in School of } \\
\text { Computing and Mathematics }\end{array}$ & Health and Science & са.10 \\
\hline Macquarie U & Group in Dept of Computing & $\begin{array}{l}\text { Information \& } \\
\text { Communication } \\
\text { Sciences }\end{array}$ & ca.5 \\
\hline Macquarie U & Group in Dept of Accounting & Economic \& & са.3 \\
\hline
\end{tabular}




\begin{tabular}{|l|l|l|c|}
\hline & \& Finance & Financial Studies & \\
\hline Macquarie U & Group of & MGSM & 1 \\
\hline Charles Sturt U & $\begin{array}{l}\text { Group in School of } \\
\text { Information Studies }\end{array}$ & $\begin{array}{l}\text { Science } \\
\text { Agriculture }\end{array}$ \\
\hline Southern Cross U & $\begin{array}{l}\text { Group in School of } \\
\text { Multimedia and IT }\end{array}$ & $\begin{array}{l}\text { Commerce and } \\
\text { Management }\end{array}$ & 12 \\
\hline U New England & Nil? & $\begin{array}{l}\text { ca.3 } \\
\text { U Newcastle }\end{array}$ & $\begin{array}{l}\text { Group in School of Design, } \\
\text { Communication and IT }\end{array}$ \\
\hline
\end{tabular}

Table 1 IS presence in NSW Universities

\section{University of New South Wales}

The School of Information Systems, Technology and Management (SISTM) has a long and varied history - there was a Department of Information Systems in the early 1980s. Today it is placed in the Commerce Faculty but does not have a core unit in that faculty's flagship BComm program. It has its own BSc in IS as well as a major in IS available in many degrees. High entrance scores are required in all programs. The distinctive BIT degree has industry training (which entails students spending a period of time working in industry during the degree studies), industry-funded student scholarships, and includes an honours year. A master's degree in IS is being started but there is support teaching for other master's degrees.

The school has long been active in research, with strong performance in quantitative aspects of IS, especially in the 1980s and early 1990s. There is also a strong performance in major research grants and doctoral student completions. With the appointment of a new head of school (Dubravka), qualitative research methods in IS are likely to become more prominent. Highly-rated IS research in management areas is conducted at the Australian Graduate School of Management (AGSM) but there is no collaboration with SISTM.

SISTM is seen to be distinct from computer science within the UNSW.

\section{University of Sydney}

As a traditional university IS at University of Sydney has until recently been primarily located in Computer Science, with a Sybase Chair in IS being appointed there in 1998, although the position is now called 'language technology' reflecting the interests of the incumbent. Other areas, such as librarianship and informatics (in the Faculty of Arts) have developed independently. The major in IS offers the same units to various degrees. There are now some 30 students (out of 100) doing an IS project in their BSc honours degree - the largest honours group in NSW. The Computer Science department is developing a masters in IT that will have an IS major.

By contrast, the newly established Business IS 'Discipline' (one of ten) in the Faculty of Commerce teaches the IS core to some 1000 students in the BComm program, aiming to recruit them to the IS major. Students in the accounting stream take additional IS units, also in MBus, MComm. A new MBusIS degree starts in 2006. The establishment of this discipline was seen as a strategic move by the dean, to give visibility and to promote interdisciplinary research. Five research areas have been selected to build strength in the group. 
There is not much visibility of information systems (in either incarnation) in the wider university community.

\section{University of Technology, Sydney}

From the days of the NSW Institute of Technology, vocationally-oriented programs have been developed. At the undergraduate level, all courses were in either part-time or "sandwich" mode, requiring students to spend usually one year in suitable paid employment before graduation. In response to an increasing number of international students and the decline of employment opportunities, industrial experience became optional in 2002, and the number of students graduating with work experience has gradually decreased. To some extent this experience is now "simulated" in a large group systems development project.

Since 1968 computing has been taught in a variety of science-oriented faculties. A second Business Information Systems group developed within the Faculty of Business. These two groups were brought together around 1980 in a Faculty of Mathematical and Computer Sciences; this faculty became the Faculty of IT in 2000. A number of conflicts between the "science" and "business" groups in the 1980s are still impacting on the Faculty. In the Faculty of IT, Information Systems was established as one of three departments but with limited autonomy. As a matter of policy, all Faculty courses are inter-departmental, as the "integration" of computer science and information systems is seen as a key strength of UTS. In the late 1990s the Faculty grew rapidly and was a strong contributor to UTS income, but the Faculty is now suffering from the reduced enrolments in IT common across the sector. This has particularly impacted the Information Systems department as it was had a large number of students from the Faculty of Business enrolled in Information Systems majors. In terms of research profile and general visibility within the University, the IS department remains relatively weak alongside the other departments. Research in the IS department took a lower profile historically and even today the proportion of staff without doctorates is comparatively high.

\section{University of Wollongong}

The IS discipline has some 400 EFTSU at the moment, making it probably the largest outside Sydney. There are both undergraduate and graduate programs. Its history goes back to 1984 when an IS group from the then Wollongong Institute joined the Commerce Faculty. In 1991 a Faculty of Informatics was created but IS stayed with Commerce. Programs were supported by the local presence of BHP, one of Australia's largest companies, and some research success was achieved in the 1990s. Currently the discipline is perceived as suffering somewhat from the increasing proportion of overseas students, difficulties in attracting research students and lack of distinctive recognition within the university.

\section{Charles Sturt, Riverina}

Charles Sturt is a multi-campus regional university, so the administrative position and visibility of IS depends to a large extent on cross-campus structure and politics. At present IS lies within the Faculty of Science and Agriculture, which controls staffing, major funding and course and subject design. At Wagga Wagga, on the other hand, arrangements have remained fairly stable, with IS as a "discipline area" in the School of Information Studies. In the past this placement has encouraged an emphasis on the "information science" aspects of IS (an aspect largely ignored elsewhere) but this specialisation is diminishing. 
As a regional university, Charles Sturt has a majority of students studying in distance mode, and has good relationships with the community, TAFE and local business (which is not strong). Research projects are mainly individual, and a number of full-time academics are currently enrolled in PhDs. Collaboration tends to be with universities in the nearby ACT rather than with the rest of NSW. Researchers do not particularly identify (or feel the need to identify) with IS as such. There is a feeling that regional universities are (for political reasons) less threatened than others by fluctuations in student demand and research fashion.

\section{RESULTS}

The following sections summarise and discuss the responses under the headings adopted by the survey instrument that is presented in Ridley (2006) in the special edition.

\section{Relative size of IS presence}

Students undertaking strongly identified IS undergraduate degrees can only be found at UNSW. UTS has an IT degree with IS as an "equal" component, and a cross-faculty business/computing degree. These universities also offer a variety of majors in non-IS programs. This format, majors in other programs, is the bread-and-butter of IS in all the other universities. The size of the IS presence therefore depends upon the university's enrolment in the core programs that offer the majors and the extent of compulsory subjects in those programs. Large accounting programs mean that many students will need to do IS and larger staff numbers are entailed. With more than 1000 students in Commerce at the University of Sydney, a larger IS unit is created.

Another characteristic is the fragmentation of IS academics across departments or faculties.

\section{Administrative placement of IS}

With the growth of enrolments in Commerce over the last 20 years, there has been some advantage to those IS units that are placed in that faculty. However, a variety of locations, especially science and computer science, persist. Most IS groups remain as ad hoc or informal groups within larger departments.

\section{Local contingencies}

It is noteworthy that when asking participants about 'local contingencies' responses reflected 'very local' issues, such as organisational politics, nearby employers and competitors. There were no "NSW" issues that came up. For example, Wollongong's support from BHP; alternative perspectives at UTS and UNSW; faculty rules at Sydney.

\section{IS as a separate field}

While the four universities highlighted have some structural recognition of IS as a separate field, it was widely held that this did not extend to the wider university communities. Indeed the interviewees would be challenged to agree on a definition of IS that was mutually satisfactory. For example, ICIS, ACIS, etc were not universally agreed as central conferences. The fragmented state at Macquarie University (ad hoc IS group in computing, accounting IS group in accounting, information management taught in statistics and IS management in the management school) is symptomatic. 


\section{Distinctive IS curricula}

The language technology emphasis in one group at U Sydney is the most distinctive. Support classes within commerce programs are possibly the least distinctive across universities. UTS has systematically innovated with specialist programs over the years, especially at the master's level. "Cooperative" programs, that is with an industrial training component, are only offered at UTS and UNSW.

\section{Distinctive features of IS research}

The IS group at UNSW has been productive over a long period particularly in quantitative aspects (some would describe as software engineering). This emphasis has declined and qualitative research is growing there. Each group at U Sydney is pursuing independent research strategies, with the scam detection project of Jon Patrick being very large, although not labelled as IS. At UTS Igor Hawryszkiewycz leads a large ongoing project on collaborative systems software, but few full-time IS staff are involved in this project. Ernest Edmonds' new "creativity and cognition" studio is under the IS umbrella, but works with computer scientists as much as with other IS academics. Large research projects in IS are otherwise few in number. Research activity tends to be fragmented and diverse.

Small research groups, especially of doctoral students, at AGSM and Macquarie Graduate School of Management (MGSM) have existed without undergraduate programs to build the staff numbers to critical mass.

\section{Perceptions of other universities}

Founding roles of UNSW, UTS and Sydney were widely recognised although there was also some recognition of interstate universities and researchers.

\section{Key people in the region}

"Round up the usual suspects". Members of ACPHIS and ACIS regulars were the most widely cited. Ron Weber has been influential outside Australia - perhaps more than inside. Dubravka Cecez-Kecmanovic and Steve Elliott are in significant strategic positions in NSW at the moment.

\section{CONCLUSION}

The already fragmented condition of IS in most universities means that with further reductions in undergraduate recruitment their positions will not improve and can deteriorate further. In the view of the authors, the strong candidates for survival and prosperity are SISTM at UNSW, and Business IS at U Sydney. The chasing pack is led by the department of IS at UTS and the IS discipline at Wollongong, which face difficulties at the moment but do have the critical mass to move forward, if the way is clear. Postgraduate specialist programs remain strong at UTS.

Research is characterised by almost no cross institution cooperation and little within institutions. The 'changing of the guard' at UNSW and U Sydney may bring about revivals. The problem will be, however, to avoid the "lost opportunities of the 70s". NSW (and Sydney in particular) had at least two institutions with plenty of highly employable undergraduate students, the respect of the IT 
industry and other institutions, and proximity to a large part of the Australian IT industry for support and research opportunities. Yet IS in the institutions failed to develop an identity or a presence. It can be argued that this was partly due to a premature desire to define a discipline. Elias (quoted in Ridley (2006)) suggests that modelling low-status on high-status disciplines is bound to fail. The moves suggested by Ridley (2006) for establishing a discipline will, if pursued by individuals or specialised research groups, work against the establishment of a broadly supported discipline. Individual prestigious reputations are established at the expense of wide collaboration, standard research methods and unique symbol systems are used to exclude rather than enrol. IS (and perhaps all new disciplines) defines itself by what it is not, particularly "not computer science". It is easy for those outside a developing prestigious group to think "but that's not really IS". The drive for academic recognition, particularly in the current university research climate, can also damage relations with industry, relations that are vital to the identity of IS. The question is, how can we build a "discipline that isn't a discipline".

\section{REFERENCES}

NSW Government (2001) “Skilling People for an Information Society”, Office for ICT, NSW Government, http://www.oict.nsw.gov.au/pdf/3.4.1-ICT-Skills.pdf, accessed March 2006

Ridley, G. (2006) “Characterising Information Systems in Australia: A Theoretical Framework”, Australasian Journal of Information Systems, Vol 13 No 3, pp. 38-60.

\section{THE AUTHORS}

Jim Underwood is a senior lecturer in the Department of Information Systems at the University of Technology, Sydney. He previously worked at the Canberra CAE and, a long time ago, in several IT consulting companies. He has also held visiting positions at UC Berkeley, LSE, Birkbeck College, Staffordshire University and University College Cork. His interests include the politics of information systems development, the dynamics of learning, and the meaning of knowledge and self in a virtual society. These are approached through the philosophical lenses of Foucault, Latour and Deleuze (amongst others). He has a PhD in Information Systems, a BSc in Pure Mathematics and Diplomas in Administration and Recreation Planning.

Professor Ernie Jordan has worked as an academic and IT practitioner in four continents and is now Professor of Management at the Macquarie Graduate School of Management in Sydney. He teaches in the areas of IT management, statistics and operations research. He is currently the Director of Higher Degrees Research at MGSM, managing the $\mathrm{PhD}$ and DBA programs. His research has specialised in the area of strategic application of information technology with an emphasis on electronic business. More recently, he has researched areas of IT risks, both strategic and operational, with significant activity in the areas of business continuity and IT governance. This work led to a recent book "Beating IT risks" with Wiley. 
